\title{
Community structure and feeding preference of nematodes associated with methane seepage at the Darwin mud volcano (Gulf of Cádiz)
}

\author{
Ellen Pape ${ }^{1, *}$, Tania Nara Bezerra ${ }^{1}$, Heleen Vanneste ${ }^{2}$, Katja Heeschen ${ }^{2}$, \\ Leon Moodley ${ }^{3}$, Frederic Leroux ${ }^{4}$, Peter van Breugel ${ }^{3}$, Ann Vanreusel ${ }^{1}$
}

\author{
${ }^{1}$ Marine Biology Section, Biology Department, Ghent University, Krijgslaan 281/S8, 9000 Gent, Belgium \\ ${ }^{2}$ National Oceanography Centre Southampton, University of Southampton, Waterfront Campus, European Way, \\ Southampton SO14 3ZH, UK
}

${ }^{3}$ Netherlands Institute of Ecology, Centre for Estuarine and Marine Ecology (NIOO-CEME), Workgroup of Ecosystem Studies, Korringaweg 7, 4401 NT Yerseke, The Netherlands

${ }^{4}$ Electron Microscopy for Materials Science (EMAT), University of Antwerp, Groenenborgerlaan 171, 2020 Antwerpen, Belgium

\begin{abstract}
We sampled the Darwin mud volcano (MV) for meiofaunal community and trophic structure in relation to pore-water geochemistry along a $10 \mathrm{~m}$ transect from a seep site on the rim of the crater towards the MV slope. Pore-water profiles indicated considerable variation in upward methane $\left(\mathrm{CH}_{4}\right)$ flow among sediment cores taken along the transect, with highest flux in the seep sediment core, gradually decreasing along the transect, to no $\mathrm{CH}_{4}$ flux in the core taken at a $5 \mathrm{~m}$ distance. Low sulphate concentrations and high levels of total alkalinity and sulphide $\left(\mathrm{H}_{2} \mathrm{~S}\right)$ suggested that anaerobic oxidation of methane (AOM) occurred close to the sediment surface in the seep sediment core. High $\mathrm{H}_{2} \mathrm{~S}$ levels had a genus- and species-specific impact on meiofaunal densities. Nematode genus composition varied gradually between sediment cores, with the genus Sabatieria dominating almost all sediment cores. However, genus diversity increased with increasing distance from the seep site. These limited data suggest that the community structure of seep meiofauna is highly dependent on local (a)biotic habitat characteristics, and a typical seep meiofaunal community cannot be delineated. Stable isotope values suggested the nematode diet up to $10 \mathrm{~m}$ from the seep site included thiotrophic carbon. The thicker hemipelagic sediment layer (photosynthetic carbon), the increased trophic diversity, and the heavier nematode $\delta^{13} \mathrm{C}$ farther from the seep site suggest a decrease in thiotrophy and an increase in photosynthetic carbon in the nematode diet.
\end{abstract}

KEY WORDS: Cold seep $\cdot$ Diversity $\cdot$ Stable isotope $\cdot$ Nematode $\cdot$ Diet

\section{INTRODUCTION}

Mud volcanoes (MVs), geological structures driven by fluid flow, are characterized by a high patchiness of biochemical and physical characteristics. Fluid flow rates, pore-water concentrations of hydrogen sulphide $\left(\mathrm{H}_{2} \mathrm{~S}\right)$ and methane $\left(\mathrm{CH}_{4}\right)$, and the thickness of the hemipelagic sediment veneer, on top of the reduced sediments can change rapidly over short distances (metres to centimetres) (Levin et al. 2003). The heterogeneity in these properties is the main parameter driving the distribution of macro- and megafauna at seeps (Levin 2005), resulting in patches of tubeworm clusters, mussels or clams, and bacterial mats or bare reduced sediments. Meiofauna can also vary on a scale of metres in taxonomic composition and biodiversity in relation to sediment biogeochemistry (Van Gaever et al. 2009c). 
There is no consistent meiofaunal response to seep conditions. Meiofaunal densities at different deepsea seeps are higher (Olu et al. 1997, Van Gaever et al. 2006) or similar (Shirayama \& Ohta 1990) compared to non-seep sediments. In seep environments, nematodes usually are the predominant metazoans, although sometimes copepods dominate (Van Gaever et al. 2006). Generally, deep-sea nematodes are characterized by high local diversity (Lambshead \& Boucher 2003). Cold seeps, however, exhibit substantially reduced species diversity, harbouring only a few dominant species (Levin 2005, Vanreusel et al. 2010). The low diversity in these habitats has been attributed to the harsh abiotic conditions, created by the high $\mathrm{H}_{2} \mathrm{~S}$ and low oxygen levels (Levin 2005).

Besides high biogeochemical and physical heterogeneity, seeps differ from most deep-sea environments in the local production of organic matter through chemosynthesis. Consequently, possible food sources for seep fauna, including meiobenthos are: (1) organic matter derived from symbiotic chemoautotrophic bacteria and (2) free-living chemoautotrophic bacteria, in addition to (3) the photosynthetic organic matter delivered to all deep-sea habitats. Studies on the diet of seep meiofauna are few. Both Van Gaever et al. (2006, 2009b) and Spies \& DesMarais (1983) found seep nematodes to be feeding on free-living sulphur-oxidising bacteria. To date, there is no evidence of symbioses between nematodes and chemosynthetic bacteria at deep-sea seeps (Vanreusel et al. 2010), and observations of symbionts associated with seep nematodes are restricted to shallow waters (Dando et al. 1991, Ott et al. 2004).

The present study examined the community structure and feeding ecology of the meiofauna, with a focus on nematodes, at a MV in the Gulf of Cádiz, which we then related to geochemical gradients along a $10 \mathrm{~m}$ transect from a seep site towards nearby hemipelagic surface sediments, and 2 sites farther away from seep influence. Our study differs from previous analyses on seep meiofauna, because it concerns isolated seep sediments on a low-activity MV. We addressed the following questions:

-Does pore-water composition influence horizontal and vertical distribution of meiofauna on a small scale?

-Are the seep sediments colonized by a specialized community that differs from the hemipelagic sediments in density, biomass and taxonomic composition (genera and species)?

-What is the nematode diet inferred from stable isotope analyses and buccal morphology? Do seep conditions influence nematode trophic diversity?

\section{MATERIALS AND METHODS}

\section{Study area}

The Gulf of Cádiz ( 34 to $37^{\circ} 15^{\prime}$ N, 9 to $6^{\circ} 45^{\prime} \mathrm{W}$ ) is a tectonically active region west of the Strait of Gibraltar, encompassing the boundary between the European and African plates. It is one of the largest coldseep areas on the European margin with $>30 \mathrm{MVs}$ between 200 and 4000 m deep (Pinheiro et al. 2003, Somoza et al. 2003, Van Rensbergen et al. 2005).

The summit (1100 $\mathrm{m}$ depth) of the Darwin MV $\left(35^{\circ} 23.51^{\prime} \mathrm{N}, 7^{\circ} 11.48^{\prime} \mathrm{W}\right.$; Fig. 1A) is covered with a large, fractured carbonate crust. At the time of sampling, countless, but mostly empty, Bathymodiolus mauritanicus shells covered the MV top (Genio et al. 2008). Living specimens were only present in small clumps along cracks in the crust. When disturbed by the remotely operating vehicle (ROV) temperature probe, a small area of dark-coloured sediment $\left( \pm 100 \mathrm{~cm}^{2}\right)$, from here on referred to as the 'seep site', emitted gas. Small carbonate blocks and white sediment, indicative of bacterial activity, which covered hard substrate, surrounded the seep site (Vanreusel et al. 2009). No dense aggregations of living chemosynthetic megafauna were associated with the seep sediments or $2 \mathrm{~m}$ away. At the MV centre, non-chemosynthetic megafauna comprised scavenging crabs, corals and stylasterine corals, attached to the carbonate crust.

\section{Sampling strategy}

Sediment cores were collected during the JC10 expedition to the Gulf of Cádiz in May 2007 onboard the RRS 'James Cook' (Table 1). We were unable to collect replicate samples because of the high heterogeneity of the habitat and the small size of the seep site. However, the present study is the first to identify potential interactions between seep meiofauna and pore-water geochemistry measured at such a small spatial scale. Furthermore, no meiofauna data were previously available from the Gulf of Cádiz, although it forms an important faunal cross road between the Mediterranean and the Atlantic.

Using ROV 'Isis', we collected 2 push cores (PUCs, $25.5 \mathrm{~cm}^{2}$ ) at each of the 4 sites along a $10 \mathrm{~m}$ transect between the seep site and an area with a considerably thicker hemipelagic sediment layer (Fig. 1, Table 1). One PUC was taken with a core-liner, with openings every $2 \mathrm{~cm}$, to extract pore-water using Rhizons (Seeberg-Elverfeldt et al. 2005). These porewaters were sub-sampled on board for nutrient and 


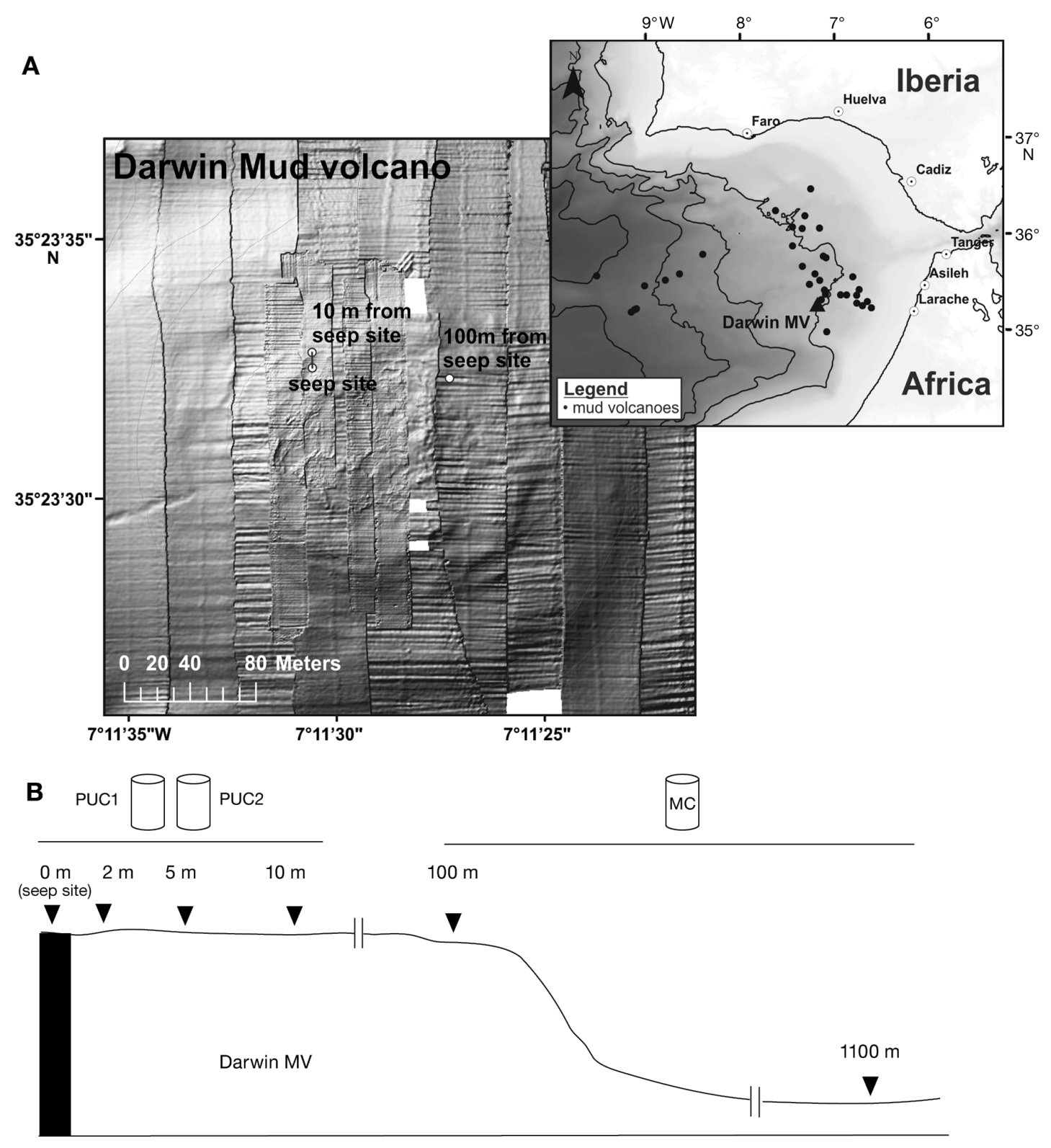

Fig. 1. Darwin mud volcano (MV). (A) Bathymetric map with the core locations on the MV indicated (courtesy of the National Oceanography Centre Southampton) (B) Schematic representation of the sampling strategy. PUC1: Push Core 1, sampled for pore-water geochemistry and meiofaunal community analyses; PUC2: Push Core 2, sampled for pore-water $\mathrm{CH}_{4}$ concen-

tration, porosity and nematode stable isotope signatures; MC: megacorer sample for meiofaunal community analyses

anion analyses. Subsequently, we sliced the top $10 \mathrm{~cm}$ of this core into $1 \mathrm{~cm}$ sections and fixed them in $4 \%$ formaldehyde for meiofaunal community analysis. The second PUC was sub-sampled for $\mathrm{CH}_{4}$ and porosity analyses, and we stored the remaining sediment in $2 \mathrm{~cm}$ slices at $-30^{\circ} \mathrm{C}$ for stable isotope analysis. Besides the $10 \mathrm{~m}$ transect, we sampled 2 sites at $\sim 100$ (on the MV) and $\sim 1100 \mathrm{~m}$ from the seep site (off the MV) with a megacorer $\left(75.4 \mathrm{~cm}^{2}\right)$. These samples were exclusively analyzed for community structure.

\section{Pore-water geochemical analyses}

Total alkalinity (TA) and hydrogen sulphide $\left(\mathrm{H}_{2} \mathrm{~S}\right)$ were measured immediately after pore-water extraction: TA by titrating against $0.05 \mathrm{M} \mathrm{HCl}$ while bubbling nitrogen through the sample (Ivanenkov \& Lyakhin 1978) and $\mathrm{H}_{2} \mathrm{~S}$ using standard photometric procedures (Grasshoff et al. 1999) adapted for pore-waters with high $\mathrm{H}_{2} \mathrm{~S}$ levels (magnitude of $\mathrm{mM}$ ). Concentrations of all other species were analyzed at 
Table 1. Sediment cores in relation to distance from the Darwin mud volcano seep site. PUC: push core, MC: megacore. 0 = seep sediment. PUC1: meiofaunal community structure and porewater geochemistry. PUC2: porosity, porewater $\mathrm{CH}_{4}$ concentration and nematode stable isotopes. MC1: Meiofaunal community structure

\begin{tabular}{|c|c|c|c|c|c|}
\hline $\begin{array}{l}\text { Distance } \\
\text { from seep } \\
\text { site }(\mathrm{m})\end{array}$ & Position & $\begin{array}{l}\text { Height hemi- } \\
\text { pelagic layer } \\
\text { (\% core length) }\end{array}$ & Gear & $\begin{array}{l}\text { No. of } \\
\text { cores }\end{array}$ & Analysis \\
\hline 0 & $\begin{array}{c}35^{\circ} 23.539^{\prime} \mathrm{N} \\
7^{\circ} 11.508^{\prime} \mathrm{W}\end{array}$ & 0 & PUC & 2 & $\begin{array}{l}\text { PUC1 } \\
\text { PUC2 }\end{array}$ \\
\hline 2 & $\begin{array}{c}35^{\circ} 23.543^{\prime} \mathrm{N} \\
7^{\circ} 11.506^{\prime} \mathrm{W}\end{array}$ & $22-33$ & PUC & 2 & $\begin{array}{l}\text { PUC1 } \\
\text { PUC2 }\end{array}$ \\
\hline 5 & $\begin{array}{c}35^{\circ} 23.543^{\prime} \mathrm{N} \\
7^{\circ} 11.509^{\prime} \mathrm{W}\end{array}$ & $53-63$ & PUC & 2 & $\begin{array}{l}\text { PUC1 } \\
\text { PUC2 }\end{array}$ \\
\hline 10 & $\begin{array}{c}35^{\circ} 23.547^{\prime} \mathrm{N} \\
7^{\circ} 11.511^{\prime} \mathrm{W}\end{array}$ & 71 & PUC & 2 & $\begin{array}{l}\text { PUC1 } \\
\text { PUC2 }\end{array}$ \\
\hline 100 & $\begin{array}{c}35^{\circ} 23.537^{\prime} \mathrm{N} \\
7^{\circ} 11.454^{\prime} \mathrm{W}\end{array}$ & 100 & $\mathrm{MC}$ & 1 & MC1 \\
\hline 1100 & $\begin{array}{c}35^{\circ} 23.965^{\prime} \mathrm{N} \\
7^{\circ} 11.121^{\prime} \mathrm{W}\end{array}$ & 100 & $\mathrm{MC}$ & 1 & MC1 \\
\hline
\end{tabular}

slice, ca. 100 nematodes were identified to genus level. Sabatieria, the dominant genus in all cores but one, was identified to species. Additionally, we measured length $\left(L_{;} \mu \mathrm{m}\right)$ and maximal width $(\mathrm{W}$; $\mu \mathrm{m})$ for each nematode from the top 0 to 5 $\mathrm{cm}$, to estimate individual biomass using Andrassy's formula (Andrassy 1956) for body wet weight (WW), adjusted for the specific gravity of marine nematodes (i.e. $\left.1.13 \mathrm{~g} \mathrm{~cm}^{-3} ; \mu \mathrm{g} \mathrm{WW}=L \times W^{2} / 1500000\right)$. $\mathrm{C}$ weight was calculated as $12.4 \%$ of wet weight (Jensen 1984).

\section{Stable isotope analysis}

Nematodes from the top $6 \mathrm{~cm}$ of each core were hand-picked for $\delta^{13} \mathrm{C}$ and $\delta^{15} \mathrm{~N}$ analysis. Desmodora $(\mathrm{n}=50)$ and Saba-

the National Oceanography Centre Southampton (NOCS). Sulphate $\left(\mathrm{SO}_{4}{ }^{2-}\right)$ was measured by ion chromatography (Dionex ICS2500), with reproducibility $>1.5 \%$ (determined by repeat analysis of a seawater standard as well as single anion standards). We measured dissolved $\mathrm{CH}_{4}$ in sediment samples taken immediately after opening the cores using the headspace vial method (Reeburgh 2007). An aliquot of sediment $\left(\sim 3 \mathrm{~cm}^{3}\right)$ was withdrawn, placed in a glass vial, and $5 \mathrm{ml}$ of $1 \mathrm{M} \mathrm{NaOH}$ was added to prevent further microbial activity (Hoehler et al. 2000). The vial was crimped shut, and the sample shaken vigorously to release the gases. $\mathrm{CH}_{4}$ concentration in the headspace was determined by gas chromatography (Agilent 6850) at the NOCS. These headspace $\mathrm{CH}_{4}$ measurements were then converted to dissolved $\mathrm{CH}_{4}$ concentrations following Hoehler et al. (2000). Depressurization and warming of the cores during sediment retrieval is likely to have led to degassing, so concentrations of $\mathrm{CH}_{4}$ (which is generally oversaturated in pore-waters) and $\mathrm{H}_{2} \mathrm{~S}$ represent minimum values. Therefore, profiles were compared relative to one another, rather than to measurements in other studies.

\section{Meiofaunal community analysis}

We washed the formaldehyde-fixed samples over a $32 \mu \mathrm{m}$ mesh sieve and extracted the meiofauna from the sediment by Ludox centrifugation (Heip et al. 1985). Meiofauna was then sorted, enumerated and identified at coarse taxonomic level. From each tieria ( $\mathrm{n}=50$ ) were picked separately, and the remaining genera were pooled to determine the 'Mix' isotope value $(\mathrm{n}=100)$. When not sufficiently abundant, Desmodora and/or Sabatieria were included in the 'Mix' sample. Nematodes were rinsed with $2 \mu \mathrm{m}$ filtered Milli-Q water, and then transferred to Milli-Q water in pre-combusted $\left(550^{\circ} \mathrm{C}, 3 \mathrm{~h}\right)$ silver cups. After elutriation, nematodes were dried overnight at $60^{\circ} \mathrm{C}$. Subsequently, we acidified samples and blanks in a desiccator containing $5 \% \mathrm{HCl}$. Isotope signatures were measured on an EA-IRMS, a Flash EA 1112 coupled to a DeltaV advantage IRMS (Thermo Electron Instruments) with a single low volume oxidation/reduction reactor (Carman \& Fry 2002). Samples were calibrated against VPDB and $\mathrm{N}_{2}$-Air with standards USGS40 and USGS41 (Qi et al. 2003), and all measurements were corrected for blanks. Isotope values were expressed in $\delta$ notation with respect to $\operatorname{VPDB}\left(\delta^{13} \mathrm{C}\right)$ and $\operatorname{air}\left(\delta^{15} \mathrm{~N}\right): \delta X(\%)=$ $\left[\left(R_{\text {sample }} / R_{\text {standard }}\right)-1\right] \times 10^{3}$, where $X$ is ${ }^{13} \mathrm{C}$ or ${ }^{15} \mathrm{~N}$ and $R$ is the isotope ratio (Post 2002).

\section{Transmission electron microscopy (TEM) and scanning transmission electron microscopy energy dispersive x-ray (STEM-EDX) analysis}

Sabatieria and Desmodora, from the seep sediment core, were imaged with TEM to check for symbionts or visible S detoxification structures. Subsequently, we conducted STEM-EDX analysis to determine the chemical composition of internal structures. Nematodes were handled following Van Gaever et al. (2009b). 


\section{Data analysis}

Individual nematode size measurements (length, width, length/width and biomass) were compared among cores using Kruskal-Wallis tests, followed by nonparametric pairwise comparisons using BehrensFisher tests with the R package npmc (Munzel \& Hothorn 2001, Helms \& Munzel 2008). Nematode size measurements were averaged per core and depth layer as geometric means corrected for data skewness (Middelburg et al. 1997, Soetaert et al. 2009). We performed multi-dimensional scaling (MDS) analysis on standardized nematode genus abundances to compare genus composition between cores. Diversity indices were $\ln \left(\log _{\mathrm{e}}\right)$-transformed to highlight differences. We examined feeding preferences based on: (1) $\delta^{13} \mathrm{C}$ and $\delta^{15} \mathrm{~N}$ of Desmodora, Sabatieria and 'Mix' and (2) buccal morphology of all genera following the classification of Wieser (1952), which assigns genera to 1 of 4 feeding types - selective deposit-feeder (1A), non-selective deposit-feeder (1B), epistrate feeder (2A) and predator/scavenger (2B). Isotope signatures were compared between Sabatieria, Desmodora and 'Mix' using 1-way ANOVA, followed by post hoc Tukey honestly significant difference tests. Trophic diversity was computed as the reciprocal of the trophic index (Heip et al. 1985). Spearman rank correlations were computed between distance from the seep site and: (1) genus diversity indices, (2) trophic diversity and (3) stable isotope signatures. We performed univariate statistical analyses using $\mathrm{R}$ ( $\mathrm{R}$ Development Core Team 2010), and multivariate analyses and computation of diversity indices in Primer v6 (Clarke \& Gorley 2006).

\section{RESULTS}

\section{Pore-water geochemistry}

Fig. 2 shows concentration-depth profiles for $\mathrm{H}_{2} \mathrm{~S}$, $\mathrm{SO}_{4}{ }^{2-}, \mathrm{CH}_{4}$ and TA in pore-water from all cores. From the 4 cores, only the seep sediment core showed a clear decrease in $\mathrm{SO}_{4}{ }^{2-}$ with depth, accompanied by a peak in $\mathrm{H}_{2} \mathrm{~S}$ (up to $22 \mathrm{mM}$ ) and an increase in $\mathrm{CH}_{4}$ and TA as high as $1000 \mu \mathrm{M}$ and 33.7 meq $\mathrm{l}^{-1}$, respectively. We observed very little change in $\mathrm{SO}_{4}{ }^{2-}$ in the core taken $2 \mathrm{~m}$ from the seep site. However, $\mathrm{H}_{2} \mathrm{~S}$, $\mathrm{CH}_{4}$ and TA were enriched in the deeper sediment layers, relative to seawater. Concentrations of all of these species in cores collected 5 and $10 \mathrm{~m}$ from the seep site were similar to seawater concentrations and varied little with depth.

\section{Meiofaunal community structure}

Meiofaunal densities were highest in the core taken $2 \mathrm{~m}$ from the seep site (3229 ind. $10 \mathrm{~cm}^{-2}$ ). Although densities in the seep sediment core $\left(795\right.$ ind. $10 \mathrm{~cm}^{-2}$ ) and in the core taken at $5 \mathrm{~m}$ distance ( 825 ind. $10 \mathrm{~cm}^{-2}$ ) were considerably lower, they were still elevated compared to those collected 10 (228 ind. $10 \mathrm{~cm}^{-2}$ ), 100 (436 ind. $10 \mathrm{~cm}^{-2}$ ) and $1100 \mathrm{~m} \mathrm{(424} \mathrm{ind.} 10 \mathrm{~cm}^{-2}$ ) from the seep site (Fig. 3). Nematodes were the most abundant taxon (88.7 to $94.5 \%$ ) in all cores (Table 2). Meiofaunal densities in the seep sediment core below $1 \mathrm{~cm}$ decreased sharply (Fig. 2). In comparison, densities in the core taken $2 \mathrm{~m}$ from the seep site decreased more gradually with depth. Meiofauna in the 2 cores retrieved farthest from seep influence penetrated deepest in the sediment.

\section{Nematode size}

Overall, total nematode biomass in the top $5 \mathrm{~cm}$ of the seep sediment core was $\sim 10 \times$ higher than that in the core taken $1100 \mathrm{~m}$ away (Fig. 3). Individual nematode size measurements (i.e. length, width and biomass) differed significantly among cores ( $p<$ 0.001; Fig. 4) and peaked in the seep sediment core. Also nematode length:width ratios varied significantly among cores $(\mathrm{p}<0.001)$, with lowest ratios in the seep sediment core (Fig. 4C). Sabatieria vasicola and $S$. punctata, which dominated the seep sediment core (Table 4), were $2417 \pm 397($ mean $\pm \mathrm{SD} \mathrm{n}=42)$ and $1131 \pm 463(\mathrm{n}=33) \mu \mathrm{m}$ long, respectively.

\section{Nematode community structure}

Nematode genus composition varied little among cores (Fig. 5, Table 3). Sabatieria dominated all samples, except at $2 \mathrm{~m}$ from the seep site, where Rhabdocoma (23\%) prevailed. All diversity indices correlated positively with distance from the seep site (Fig. 6), but these correlations were significant only for $N_{0}$ and $\mathrm{EG}(100)\left(N_{0}: \mathrm{r}=0.93, \mathrm{p}=0.008\right.$ and $\mathrm{EG}(100): \mathrm{r}=0.81$, $\mathrm{p}=0.049$ ). Desmodora was only abundant (i.e. $\geq 1 \%$ of total) in cores within $5 \mathrm{~m}$ off the seep (Table 3). The Sabatieria species composition of all sediment cores is presented in Table 4.

\section{Nematode feeding preference}

$\delta^{13} \mathrm{C}$ ranged between -40.7 and $-21.3 \%$, and $\delta^{15} \mathrm{~N}$ between 0.9 and $15.3 \%$ (Fig. 7$) \cdot \delta^{13} \mathrm{C}(\mathrm{r}=0.34, \mathrm{p}=$ 


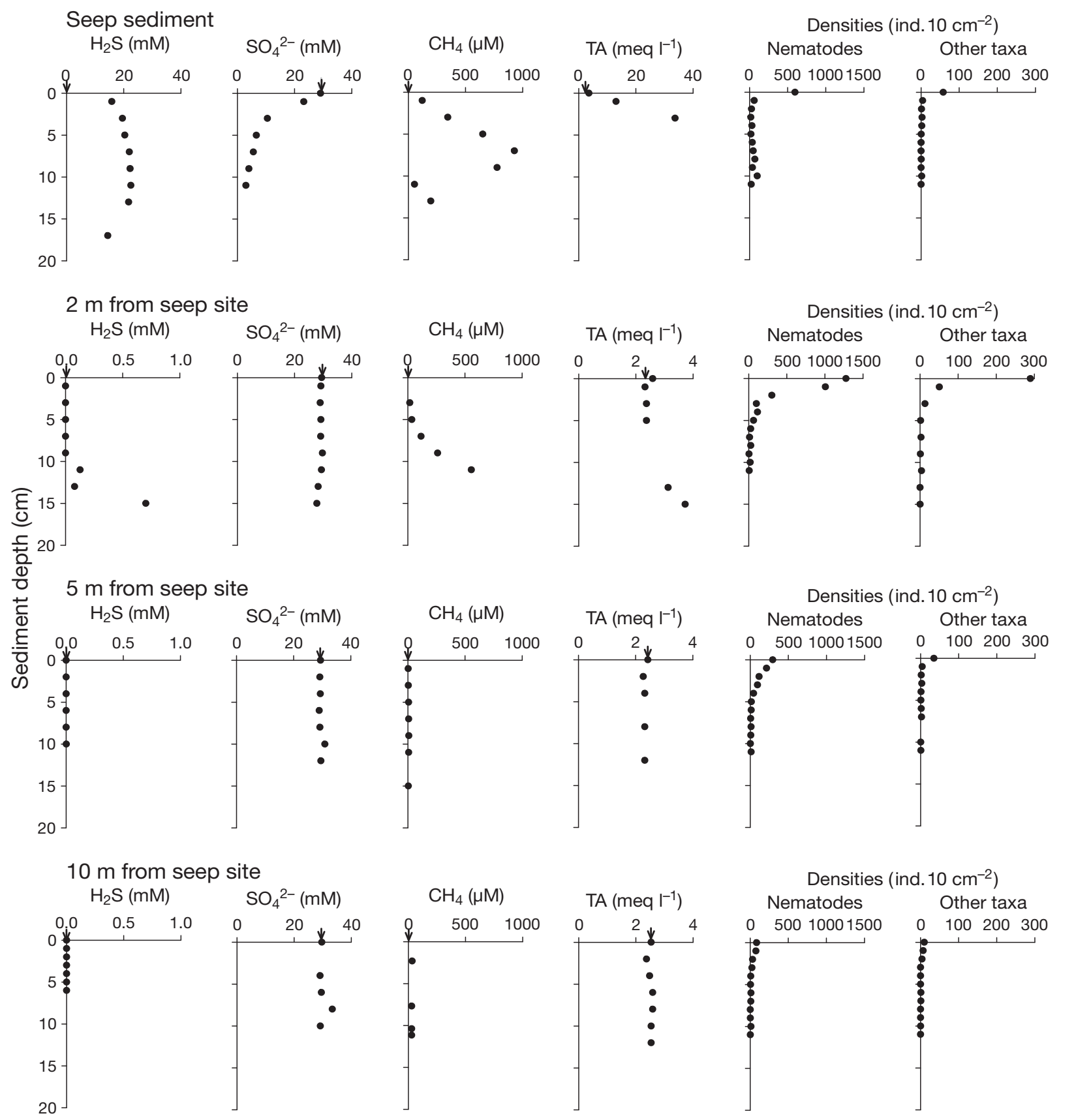

Fig. 2. Vertical pore-water profiles of $\mathrm{H}_{2} \mathrm{~S}, \mathrm{SO}_{4}{ }^{2-}, \mathrm{CH}_{4}$ and total alkalinity (TA), and densities of nematodes and other meiofaunal taxa in relation to distance from the Darwin mud volcano seep site. Vertical arrows on x-axes indicate seawater values.

Note the different scales on the $\mathrm{x}$-axes

$0.14)$ and $\delta^{15} \mathrm{~N}(\mathrm{r}=0.24, \mathrm{p}=0.28)$ became heavier with increasing distance from the seep site, though the correlations were not significant. No clear pattern emerged when plotting stable isotope signatures (mean $\pm \mathrm{SD}$ ) versus sediment depth (Fig. 7). 'Mix' $\left(\delta^{13} \mathrm{C}:-31.2 \pm 4.9 \%\right.$; $\delta^{15} \mathrm{~N}: 7.11 \pm 3.9 \%$ o $)$ was significantly more enriched in ${ }^{13} \mathrm{C}(\mathrm{p}=0.02)$ and ${ }^{15} \mathrm{~N}(\mathrm{p}=$ $0.02)$ than Desmodora $\left(\delta^{13} \mathrm{C}:-38.5 \pm 2.0 \% ; \delta^{15} \mathrm{~N}: 4.6 \pm\right.$
$2.2 \%)$. Sabatieria $\left(\delta^{13} \mathrm{C}:-36.3 \pm 2.4 \% ; \delta^{15} \mathrm{~N}: 6.9 \pm\right.$ $1.5 \%$ ) and Desmodora displayed similar isotope values $\left(\delta^{13} \mathrm{C}: \mathrm{p}=0.67 ; \delta^{15} \mathrm{~N}: \mathrm{p}=0.43\right)$. Based on buccal morphology, deposit-feeders $(1 \mathrm{~A}+1 \mathrm{~B})$ dominated all cores (data not shown), although trophic diversity increased with increasing distance from the seep site $(\mathrm{r}=0.70, \mathrm{p}=0.12)$ and levelled off at $10 \mathrm{~m}$ distance (Fig. 8). 


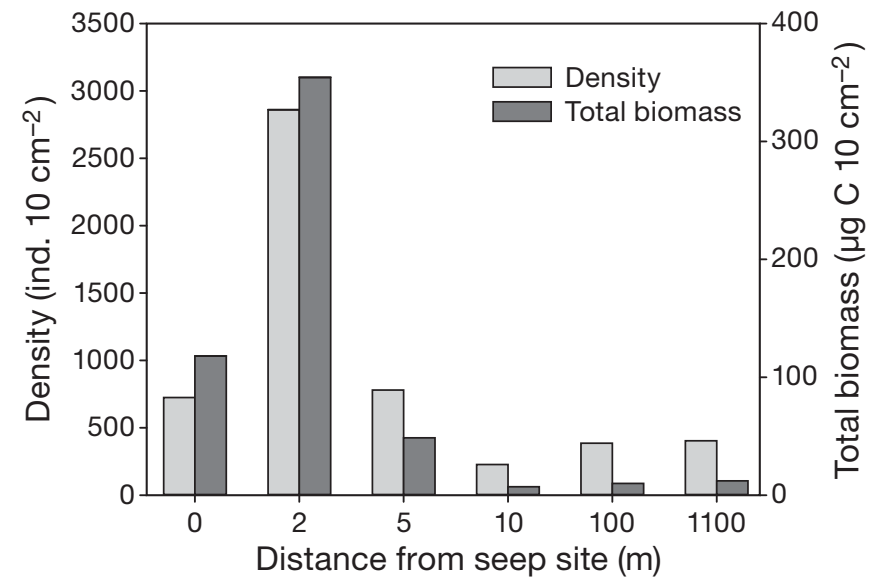

Fig. 3. Total nematode densities and biomass in the top $5 \mathrm{~cm}$ of the sediment cores in relation to distance from the Darwin mud volcano seep site $(0=$ seep sediment $)$

\section{TEM and STEM-EDX}

TEM revealed several, but mostly disintegrated bacteria bordering the cuticle of Desmodora (Fig. 9). Additionally, electron-lucent structures were observed near the cuticle (Fig. 9B). STEM-EDX analysis showed these contained trace amounts of sulphur. We observed no symbionts or detoxification structures in Sabatieria.

Table 2. Meiofaunal densities (ind. $10 \mathrm{~cm}^{-2}$ ) in the top $5 \mathrm{~cm}$ of the sediment cores in relation to distance from the Darwin mud volcano seep site ( 0 = seep sediment $)$

\begin{tabular}{|c|c|c|c|c|c|c|}
\hline \multirow[t]{2}{*}{ Taxon } & \multirow[b]{2}{*}{0} & \multicolumn{5}{|c|}{ Distance from seep site $(\mathrm{m})$} \\
\hline & & 2 & 5 & 10 & 100 & 1100 \\
\hline Amphipoda & - & 0.8 & - & - & - & - \\
\hline Bivalvia & 2.0 & - & 1.2 & - & 0.1 & - \\
\hline Cladocera & - & - & - & 0.4 & - & - \\
\hline $\begin{array}{l}\text { Cnidaria } \\
\text { Copepoda }\end{array}$ & 0.4 & 4.3 & - & 0.8 & - & 0.3 \\
\hline Adults & 7.8 & 122 & 12.5 & 3.9 & 16.9 & 7.7 \\
\hline Nauplii & 9.8 & 155 & 9.4 & 4.7 & 11.1 & 2.5 \\
\hline Cumacea & - & - & - & 0.4 & 0.3 & 0.1 \\
\hline Gastrotricha & 0.4 & - & 1.6 & - & - & - \\
\hline Halacaroidea & 4.7 & 2.7 & 0.4 & - & - & - \\
\hline Holothuroidea & - & 1.2 & - & - & 7.7 & 0.4 \\
\hline Isopoda & - & 3.9 & 0.4 & 0.4 & 0.9 & 0.1 \\
\hline Kinorhyncha & 0.8 & - & - & 0.4 & - & - \\
\hline Nematoda & 725 & 2860 & 780 & 228 & 388 & 405 \\
\hline Oligochaeta & 0.8 & 9.8 & 5.1 & - & - & 0.1 \\
\hline Ostracoda & - & 0.8 & 1.6 & - & 1.1 & 0.4 \\
\hline Polychaeta & 42.7 & 54.5 & 7.1 & 9.8 & 8.7 & 5.9 \\
\hline Tanaidacea & - & 3.5 & 0.8 & 0.4 & - & - \\
\hline Tardigrada & - & 8.6 & 5.9 & - & 1.5 & 1.2 \\
\hline Total & 794 & 3227 & 825 & 248 & 436 & 424 \\
\hline
\end{tabular}
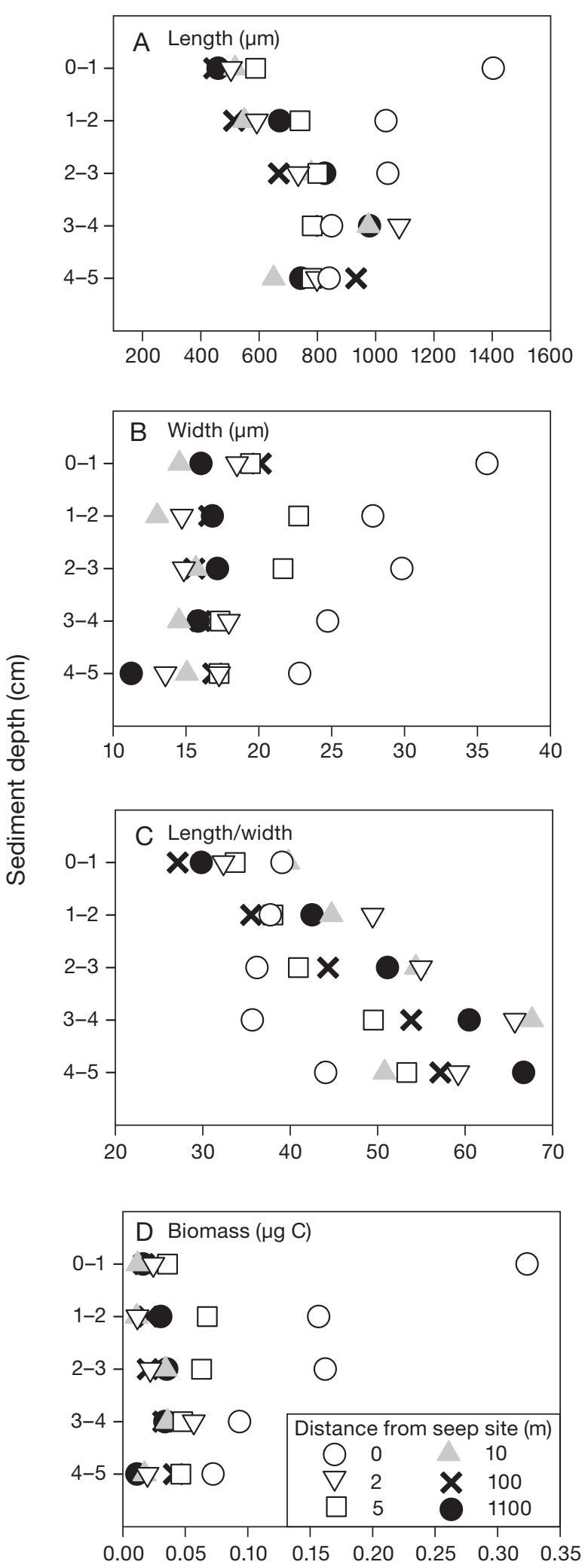

Fig. 4. Mean nematode (A) length, (B) width, (C) length: width and (D) biomass as a function of sediment depth $(\mathrm{cm})$, in relation to distance from the Darwin mud volcano seep site. $0=$ seep sediment 


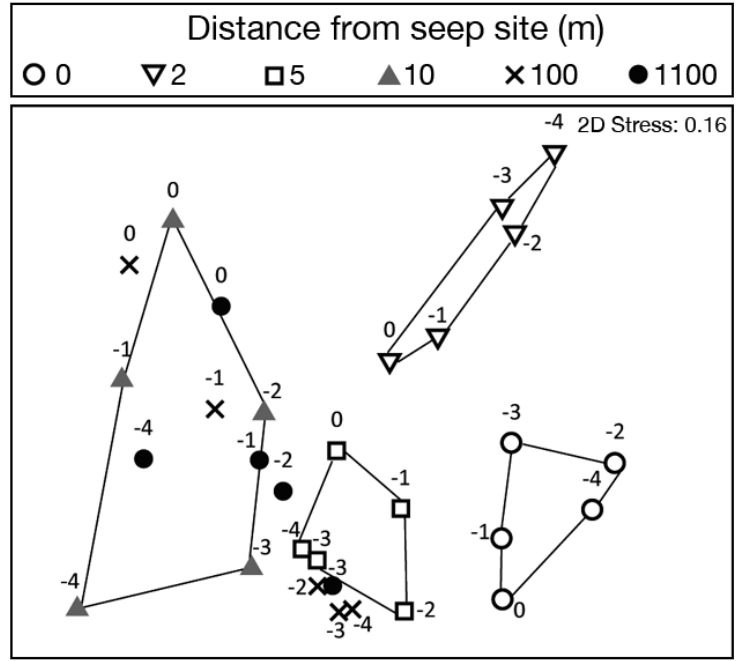

Fig. 5. Multi-dimensional scaling plot of standardized genus-abundance data in relation to distance from the Darwin mud volcano seep site. Numbers = sediment depth $(\mathrm{cm}) .0=$ seep sediment. Contour plots for the cores collected at 100 and $1100 \mathrm{~m}$ from the seep site overlap and are not shown

\section{DISCUSSION}

\section{$\mathrm{CH}_{4}$ seepage and spatial variability in pore-water geochemistry}

Elevated pore-water $\mathrm{CH}_{4}$ levels in the Darwin MV seep sediment core indicated a $\mathrm{CH}_{4}$ flux from below the sediment surface, corroborating the gas escape from the seep sediments during sampling. However, $\mathrm{CH}_{4}$ concentrations dropped from $1 \mathrm{mM}$ down to $<0.001 \mathrm{mM}$ over a $10 \mathrm{~m}$ distance, suggesting focused flow. Porefluid analyses indicated some anaerobic consumption by microbes (i.e. anaerobic oxidation of methane, $\mathrm{AOM}$ ): $\mathrm{SO}_{4}{ }^{2}$ decreased rapidly with depth in the seep site pore-fluids, accompanied by an increase in TA and elevated $\mathrm{H}_{2} \mathrm{~S}$ concentrations (Reeburgh 1976, Boetius et al. 2000, Knittel \& Boetius 2009). The relatively small enrichments in $\mathrm{H}_{2} \mathrm{~S}, \mathrm{CH}_{4}$ and $\mathrm{TA}$ in the core taken $2 \mathrm{~m}$ from the seep site suggest AOM presence here as well, but likely concentrated at depths exceeding the core length. The constancy in the concentrations of $\mathrm{SO}_{4}{ }^{2}, \mathrm{TA}, \mathrm{H}_{2} \mathrm{~S}$ and $\mathrm{CH}_{4}$ with depth in the cores taken at 5 and $10 \mathrm{~m}$ distance suggest an absence of AOM. The high spatial variability in $\mathrm{CH}_{4}$ flow at the Darwin MV illustrates the difficulty in taking replicate samples for pore-water geochemistry and associated fauna at seeps.

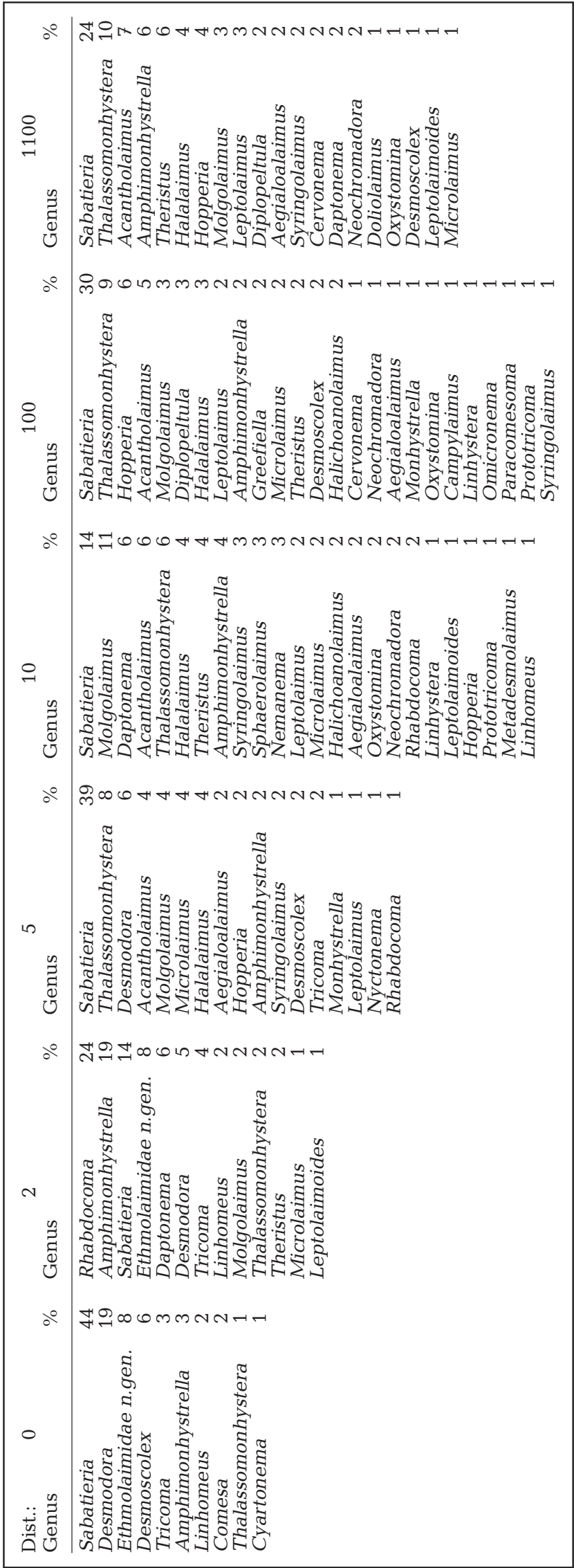


Table 4. Relative abundance of Sabatieria species (\%) in the top $5 \mathrm{~cm}$ of the sediment cores in relation to distance (Dist.; $\mathrm{m}$ ) from the Darwin mud volcano seep site $(0=$ seep sediment $)$

\begin{tabular}{|c|c|c|c|c|c|c|c|c|c|c|c|}
\hline \multirow{2}{*}{$\begin{array}{ll}\text { Dist.: } & 0 \\
\text { Species } & \end{array}$} & \multirow[b]{2}{*}{$\%$} & \multicolumn{2}{|l|}{2} & \multicolumn{2}{|l|}{5} & \multicolumn{2}{|l|}{10} & \multicolumn{2}{|l|}{100} & \multicolumn{2}{|l|}{1100} \\
\hline & & Species & $\%$ & Species & $\%$ & Species & $\%$ & Species & $\%$ & Species & $\%$ \\
\hline S. vasicola & 29 & S. bitumen & 38 & S. bitumen & 41 & S. bitumen & 40 & S. ornata & 11 & S. stekhoveni & 52 \\
\hline S. punctata & 21 & S. ornata & 35 & S. aff. breviseta & 16 & S. stekhoveni & 20 & S. bitumen & 10 & S. aff. breviseta & 10 \\
\hline S. stekhoveni & 18 & S. propisinna & 18 & S. propisinna & 16 & S. ornata & 16 & S. demani & 7 & S. propisinna & 8 \\
\hline S. ornata & 10 & S. stekhoveni & 10 & S. demani & 12 & S. propisinna & 13 & S. stekhoveni & 5 & S. conicauda & 7 \\
\hline S. aff. breviseta & 8 & & & S. stekhoveni & 12 & S. demani & 12 & S. aff. breviseta & 3 & S. demani & 6 \\
\hline S. conicauda & 5 & & & S. ornata & 3 & & & S. conicauda & 3 & S. lawsi & 6 \\
\hline S. demani & 5 & & & & & & & S. punctata & 2 & S. ornata & 6 \\
\hline & & & & & & & & & & S. punctata & 4 \\
\hline & & & & & & & & & & S. vasicola & 3 \\
\hline
\end{tabular}

\section{Effect of pore-water geochemistry on meiofaunal distribution and tolerance to high $\mathrm{H}_{2} \mathrm{~S}$ levels}

At the Darwin MV, meiofaunal densities were much higher in and immediately near the seep site ( $2 \mathrm{~m})$ compared to at the sites showing no sign of seep influence in terms of pore-water geochemistry. Accordingly, Vanreusel et al. (2010) showed elevated meiofaunal standing stock in seep compared to non-seep sediments for several other seep systems. The seep sediment core had high $\mathrm{H}_{2} \mathrm{~S}$ content (up to $22 \mathrm{mM}$ ), as shown for several other seeps (Barry et al. 1997, Sahling et al. 2002, Levin et al. 2003). These high $\mathrm{H}_{2} \mathrm{~S}$ levels affected the vertical distribution in the sediment, in that the proportion of meiofauna confined to the sediment surface was highest in this core. Tolerance of high $\mathrm{H}_{2} \mathrm{~S}$ levels was genus (and species) specific. Sabatieria and Desmodora, which dominated the seep sediment core, were more tolerant to high $\mathrm{H}_{2} \mathrm{~S}$ than genera absent from this core.

In sulphidic environments, bacterial symbionts can help to detoxify $\mathrm{H}_{2} \mathrm{~S}$ (Ott et al. 2004). In bathyal oxygen minimum zone sediments, Desmodora masira had ectosymbionts (Bernhard et al. 2000). Although in our study, TEM cross-sections paralleled the annuli (in contrast to Bernhard et al. 2000), the low and irregular bacterial appearance implies that Desmodora from the seep sediment core did not harbour ectosymbionts. TEM showed electron-lucent structures near the cuticle resembling the sulphur inclusions described by Thiermann et al. (2000), but STEM-EDX analysis only detected traces of sulphur. However, elemental sulphur is known to leach from vesicles during the chemical fixation, dehydration and resin infiltration of biological samples, which may explain the low sulphur content (Lechaire et al. 2006). Increased body length is another adaptation to sulphidic conditions, and enables a fast migration between anoxic, sulphidic and oxic $\mathrm{H}_{2} \mathrm{~S}$-free sedi- ments (Schratzberger et al. 2004, Levin 2005). Accordingly, Sabatieria punctata and $S$. vasicola, which dominated the seep sediment core, were amongst the longest nematodes in the present study.

\section{Meiofaunal and nematode community structure}

Meiofaunal density patterns were mainly driven by the dominant taxon, i.e. the nematodes. Nematodes dominate most seep habitats (Shirayama \& Ohta 1990, Robinson et al. 2004, Van Gaever et al. 2009a, Van Gaever et al. 2009c), although some habitats are

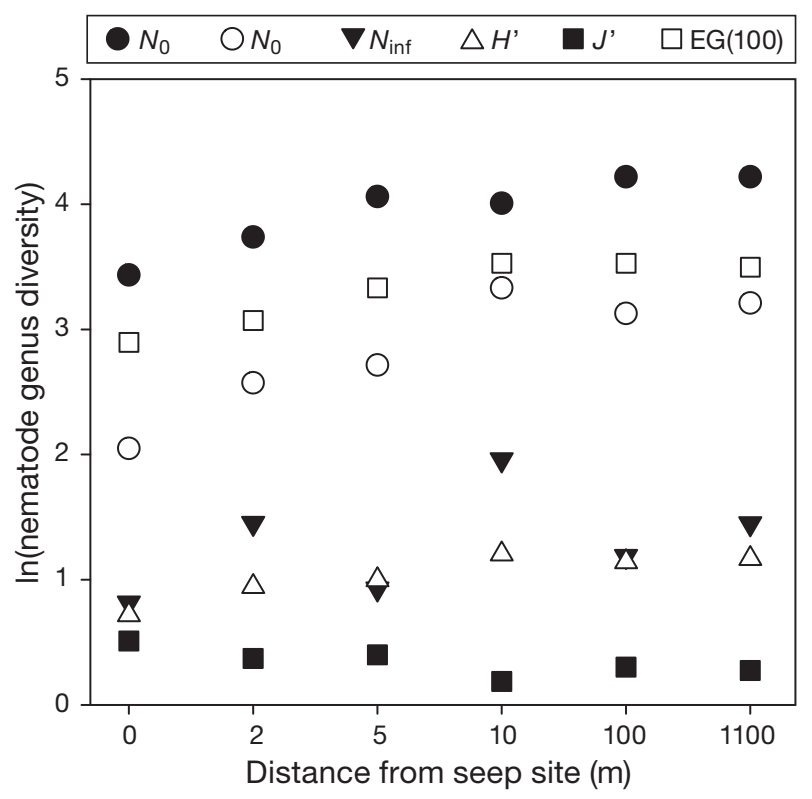

Fig. 6. ln-transformed diversity indices based on abundances of nematode genera in relation to distance from the Darwin mud volcano seep site. $N_{0}, N_{1}, N_{\text {inf }}$ : Hill's numbers; $H^{\prime}$ : Shannon-Wiener diversity index; $J^{\prime}$ : Pielou's evenness number; EG(100): expected number of genera for $n=100$. 

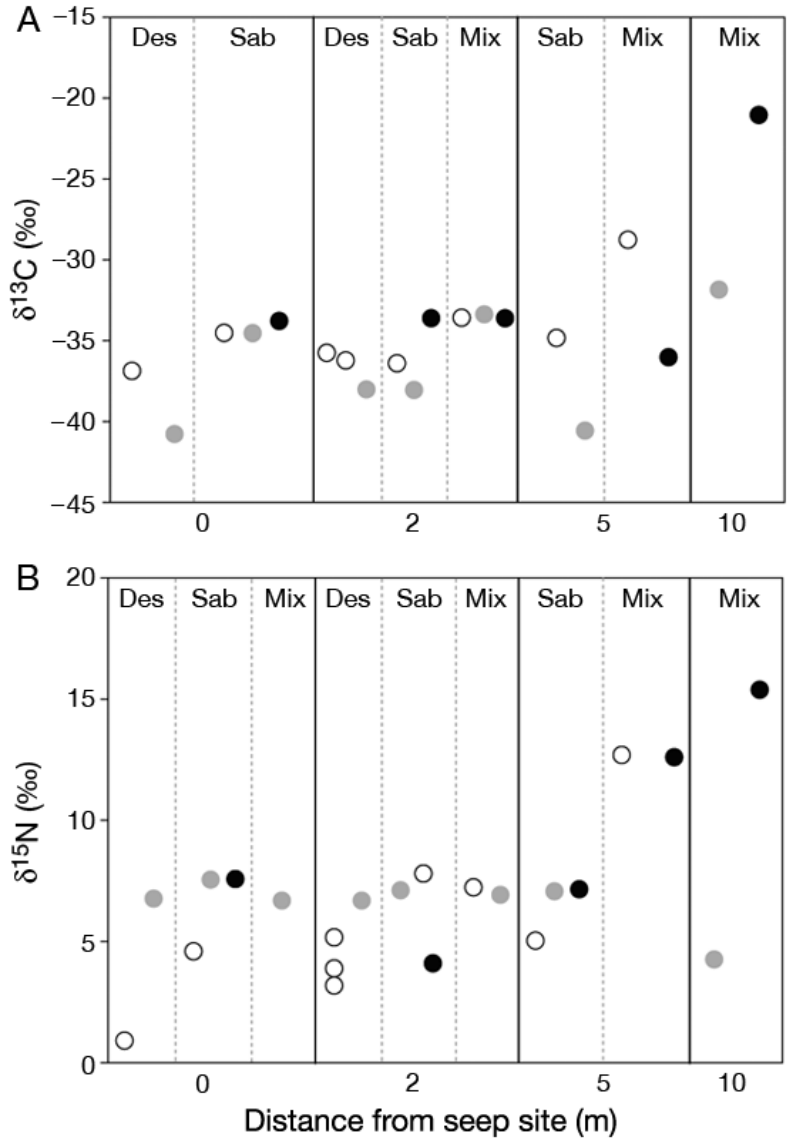

Fig. 7. Desmodora (Des), Sabatieria (Sab) and 'Mix' (A) carbon and (B) nitrogen isotope signatures in relation to distance from the Darwin mud volcano seep site. $0=$ seep sediment. At $10 \mathrm{~m}$ distance, no $\delta^{13} \mathrm{C}$ was available for 0 to $2 \mathrm{~cm}$ due to the low amount of $\mathrm{C}$, making the isotope value unreliable. Sediment layers: $\mathrm{O}=0$ to $2 \mathrm{~cm} ; \mathrm{O}=2$ to $4 \mathrm{~cm} ; \bullet=$ 4 to $6 \mathrm{~cm}$

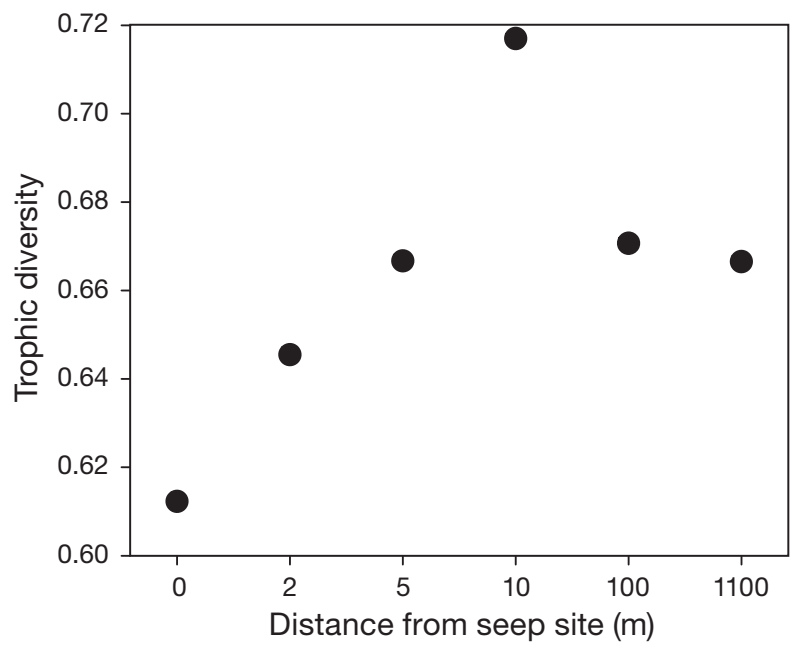

Fig. 8. Nematode trophic diversity in the top $5 \mathrm{~cm}$ of the sediment cores in relation to distance from the Darwin mud volcano seep site $(0=$ seep sediment $)$

dominated by copepods (Van Gaever et al. 2006). In the Darwin MV seep sediment core, meiofauna-sized polychaetes were subdominant, similar to the mussel beds at the REGAB seep (Van Gaever et al. 2009a).

Nematode genus composition clearly differed between cores with and without $\mathrm{CH}_{4}$ flow. Thus, $\mathrm{CH}_{4}$ flow affected not only densities and biomass, but also composition. Genus diversity was lowest in the seep sediment core and increased in cores farther from the seep site, as shown in previous studies (Van Gaever et al. 2009a,c). Desmodora and Sabatieria also dominated the REGAB seep in the Gulf of Guinea (Van Gaever et al. 2009a), although in association with different habitats: the REGAB samples originated
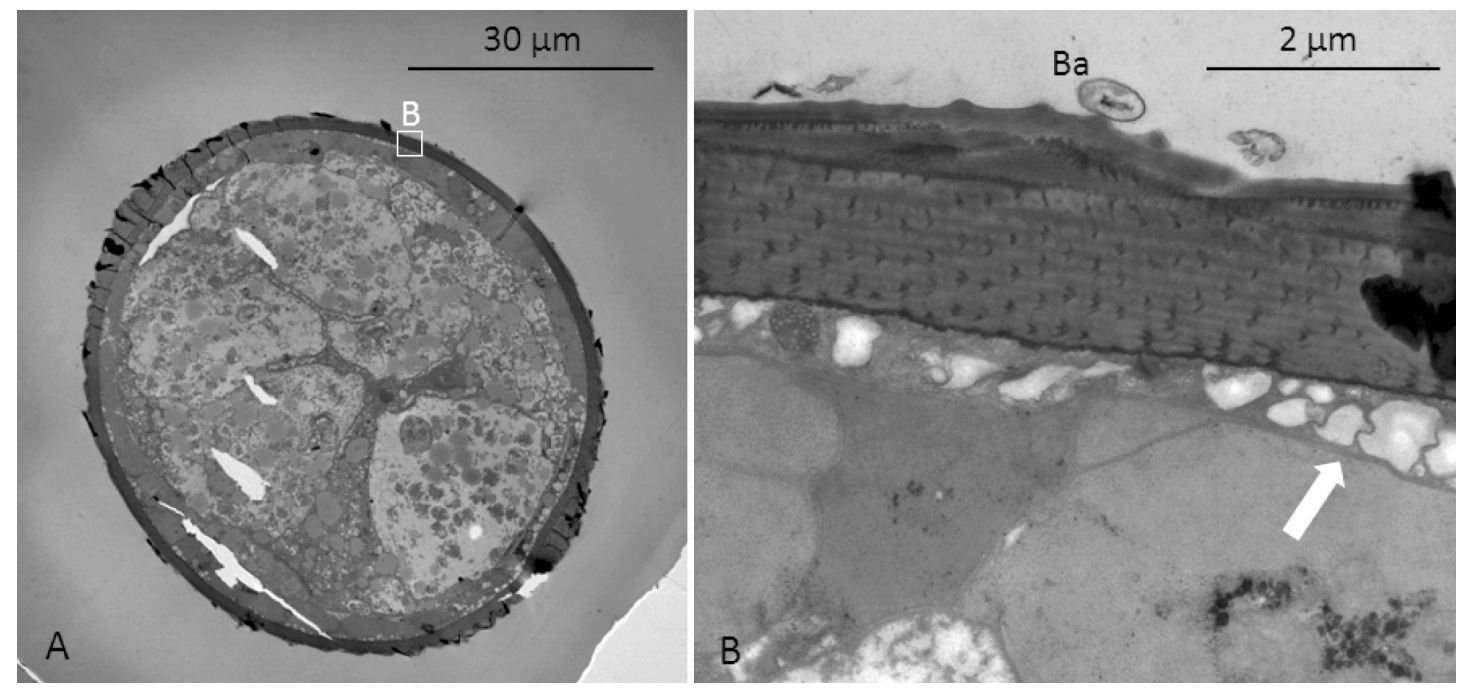

Fig. 9. Transmission electron microscope micrograph of a cross-section of Desmodora from the Darwin mud volcano seep sediment core: (A) overview and (B) detailed depiction showing bacteria associated with the cuticle. The white arrow points to electronlucent structures, possibly containing sulphur prior to ethanol dehydration. Ba: bacterial cell 
from clam and mussel fields with low $\mathrm{H}_{2} \mathrm{~S}$ content $\left(<0.1 \mu \mathrm{M}_{i}\right.$ Olu et al. 2009). S. vasicola and S. punctata, which dominated the Darwin MV seep sediment core, also occur in shallow waters (Vitiello 1970, Jensen et al. 1992, Franco et al. 2008). Accordingly, the dominant species at the REGAB seep ( $S$. mortenseni), the Arctic Håkon Mosby MV (Halomonhystera disjuncta) (Van Gaever et al. 2006) and the Nordic Nyegga seep (Terschellingia longicaudata) (Van Gaever et al. 2009c) inhabit shallow waters as well. The presence of these species in both shallow waters and at a deep-sea seep suggests a possible connection between these habitats, rather than between deep-sea seeps (Van Gaever et al. 2009c).

\section{Nematode feeding preferences}

$\delta^{13} \mathrm{C}$ values suggest thiotrophic $\mathrm{C}$ is part of the nematode diet up to $10 \mathrm{~m}$ from the seep site. Except for 'Mix' in the 4 to $6 \mathrm{~cm}$ sediment layer, which displays a $\delta^{13} \mathrm{C}$ of $-21.3 \%$, all $\delta^{13} \mathrm{C}$ were less than $-28 \%$. Organic matter produced through sulphur-oxidation has an average $\delta^{13} \mathrm{C}$ of $-30 \%$ (RubisCO I) or $-11 \%$ (RubisCO II), depending on the Rubisco enzyme involved (Robinson \& Cavanaugh 1995). In comparison, photosynthetic $\mathrm{C}$ is characterized by a $\delta^{13} \mathrm{C}$ of between -18 and $-28 \%$ (Stewart et al. 2005), and $\mathrm{CH}_{4}$-derived $\mathrm{C}$ is more depleted in ${ }^{13} \mathrm{C}\left(\delta^{13} \mathrm{C}<-50 \%\right)$ (Levin \& Michener 2002). Since we did not sample potential C sources for stable isotope analysis, we cannot estimate their relative contribution to the nematode diet. Nonetheless, a decrease in thiotrophic (RubisCO I) and an increase in photosynthetic $\mathrm{C}$ in the nematode diet farther from the seep site are implied by: (1) the thicker hemipelagic sediment veneer on top of the cores, suggesting a higher availability of photosynthetic $\mathrm{C}_{1}(2)$ an increase in trophic diversity, and (3) heavier $\delta^{13} \mathrm{C}$.

Spies \& DesMarais (1983) and Van Gaever et al. $(2006,2009 b)$ reported direct nematode consumption of sulphur-oxidisers. These bacteria live at the interface between oxic and anoxic sediments, where $\mathrm{H}_{2} \mathrm{~S}$ levels are $\leq 1 \mu \mathrm{M}$ (Robertson \& Kuenen 2006, Preisler et al. 2007). We doubt these bacteria inhabited the seep sediments given the absence of bacterial mats and the high $\mathrm{H}_{2} \mathrm{~S}$ levels at greater depth. In the core collected $2 \mathrm{~m}$ from the seep site, we observed no net $\mathrm{SO}_{4}{ }^{2-}$ production, expected in the presence of sulphur-oxidisers. Nematodes can indirectly consume sulphur-oxidisers by assimilating dissolved organic matter (DOM) released upon bacterial lysis. Jensen (1987) suggested thiobiotic nematodes feed, at least partially, on DOM. However, further evidence is needed to support this hypothesis. Stable isotope signatures suggest different feeding strategies for Sabatieria and Desmodora compared with the bulk nematode community, which may explain their success. As with other seeps (Vanreusel et al. 2010), deposit-feeders dominated. Finally, although this exploratory study hints at how meiofauna interact with the seep environment, much more, high-resolution research is required to understand their tolerance of sulphide, trophic interactions and dispersal capacities.

Acknowledgements. The research leading to these results has received funding from the European Community's Seventh Framework Programme (FP7/2007-2013) under the HERMIONE project, grant agreement no. 226354, and was supported by the FWO 'cold seeps' project No. G034607. The authors are greatly indebted to the crew and captain of the RRS 'James Cook' and the pilots of ROV 'Isis' for their expertise and professionalism. We also gratefully acknowledge $M$. Claeys for her assistance and the preparation of the TEM photographs. Finally, yet importantly, we greatly appreciated the comments of the editor, the reviewers and Lois Maignien.

\section{LITERATURE CITED}

Andrassy I (1956) The determination of volume and weight of nematodes. Acta Zool Hung 2:1-15

Barry JP, Kochevar RE, Baxter CH (1997) The influence of pore-water chemistry and physiology on the distribution of vesicomyid clams at cold seeps in Monterey Bay: implications for patterns of chemosynthetic community organization. Limnol Oceanogr 42:318-328

Bernhard JM, Buck KR, Farmer MA, Bowser SS (2000) The Santa Barbara Basin is a symbiosis oasis. Nature 403: 77-80

> Boetius A, Ravenschlag K, Schubert CJ, Rickert D and others (2000) A marine microbial consortium apparently mediating anaerobic oxidation of methane. Nature 407:623-626

> Carman KR, Fry B (2002) Small-sample methods for delta $\delta^{13} \mathrm{C}$ and delta $\delta^{15} \mathrm{~N}$ analysis of the diets of marsh meiofaunal species using natural-abundance and traceraddition isotope techniques. Mar Ecol Prog Ser 240:85-92

Clarke K, Gorley R (2006) PRIMER v6: user manual/tutorial. Primer-E Ltd, Plymouth

Dando PR, Austen MC, Burke RA, Kendall MA and others (1991) Ecology of a North Sea pockmark with an active methane seep. Mar Ecol Prog Ser 70:49-63

> Franco MA, Soetaert K, Van Oevelen D, Van Gansbeke D, Costa MJ, Vincx M, Vanaverbeke J (2008) Density, vertical distribution and trophic responses of metazoan meiobenthos to phytoplankton deposition in contrasting sediment types. Mar Ecol Prog Ser 358:51-62

> Genio L, Johnson SB, Vrijenhoek RC, Cunha MR, Tyler PA, Kiel S, Little CTS (2008) New record of 'Bathymodiolus' mauritanicus Cosel, 2002 from the Gulf of Cadiz (NE Atlantic) mud volcanoes. J Shellfish Res 27:53-61

Grasshoff K, Ehrhardt M, Kremling K, Anderson L (1999) Methods of seawater analysis. Wiley-VCH, Weinheim 
Heip C, Vincx M, Vranken G (1985) The ecology of marine nematodes. Oceanogr Mar Biol Annu Rev 23:399-489

Helms J, Munzel U (2008) NPMC: nonparametric multiple comparisons. R package version 10-7, accessed 17 April 2009

Hoehler T, Borowski W, Alperin M, Rodriguez N, Paull C (2000) Model, stable isotope and radiotracer characterization of anaerobic methane oxidation in gas hydratebearing sediments of the blake ridge. Proc Ocean Drill Program, Sci Results 164:79-85

Ivanenkov V, Lyakhin Y (1978) Determination of total alkalinity in seawater. In: Methods of hydrochemical investigations in the ocean. Nauka Publ. House, Moscow, p 110-114

Jensen P (1984) Measuring carbon content in nematodes. Helgol Meeresunters 38:83-86

> Jensen P (1987) Feeding ecology of free-living aquatic nematodes. Mar Ecol Prog Ser 35:187-196

Jensen P, Aagaard I, Burke RA, Dando PR and others (1992) 'Bubbling Reefs' in the Kattegat: submarine landscapes of carbonate-cemented rocks support a diverse ecosystem at methane seeps. Mar Ecol Prog Ser 83:103-112

Knittel K, Boetius A (2009) Anaerobic oxidation of methane: progress with an unknown process. Annu Rev Microbiol 63:311-334

Lambshead PJD, Boucher G (2003) Marine nematode deepsea biodiversity-Hyperdiverse or hype? J Biogeogr 30: 475-485

Lechaire JP, Frébourg G, Gaill F, Gros O (2006) In situ localization of sulphur in the thioautotrophic symbiotic model Lucina pectinata (Gmelin, 1791) by cryo-EFTEM microanalysis. Biol Cell 98:163-170

> Levin LA (2005) Ecology of cold seep sediments: interactions of fauna with flow, chemistry and microbes. Oceanogr Mar Biol Annu Rev 43:1-46

> Levin LA, Michener RH (2002) Isotopic evidence for chemosynthesis-based nutrition of macrobenthos: the lightness of being at Pacific methane seeps. Limnol Oceanogr 47:1336-1345

> Levin LA, Ziebis W, Mendoza GF, Growney VA and others (2003) Spatial heterogeneity of macrofauna at northern California methane seeps: influence of sulfide concentration and fluid flow. Mar Ecol Prog Ser 265:123-139

Middelburg JJ, Soetaert K, Herman PMJ (1997) Empirical relationships for use in global diagenetic models. DeepSea Res I 44:327-344

Munzel U, Hothorn LA (2001) A unified approach to simultaneous rank test procedures in the unbalanced one-way layout. Biom J 43:553-569

Olu Roy K, Lance S, Sibuet M, Henry P, Fiala-Medioni A, Dinet A (1997) Cold seep communities as indicators of fluid expulsion patterns through mud volcanoes seaward of the Barbados accretionary prism. Deep-Sea Res I 44: 811-841

> Olu Roy K, Caprais JC, Galéron J, Causse R and others (2009) Influence of seep emission on the non-symbiontbearing fauna and vagrant species at an active giant pockmark in the Gulf of Guinea (Congo-Angola margin). Deep-Sea Res II 56:2380-2393

Ott J, Bright M, Bulgheresi S (2004) Symbioses between marine nematodes and sulfur-oxidizing chemoautotrophic bacteria. Symbiosis 36:103-126

Pinheiro LM, Ivanov MK, Sautkin A, Akhmanov G and others (2003) Mud volcanism in the Gulf of Cadiz: results from the TTR-10 cruise. Mar Geol 195:131-151
Post DM (2002) Using stable isotopes to estimate trophic position: models, methods, and assumptions. Ecology 83: 703-718

Preisler A, de Beer D, Lichtschlag A, Lavik G, Boetius A, Jorgensen BB (2007) Biological and chemical sulfide oxidation in a Beggiatoa inhabited marine sediment. ISME J 1:341-353

Qi H, Coplen TB, Geilmann H, Brand WA, Bohlke JK (2003) Two new organic reference materials $\delta^{13} \mathrm{C}$ and $\delta^{15} \mathrm{~N}$ measurements and a new value for the $\delta^{13} \mathrm{C}$ of NBS 22 oil. Rapid Commun Mass Spectrom 17:2483-2487

R Development Core Team (2010) R: a language and environment for statistical computing. R Foundation for Statistical Computing, Vienna. Available at www.Rproject.org

Reeburgh WS (1976) Methane consumption in Cariaco Trench waters and sediments. Earth Planet Sci Lett 28: 337-344

Reeburgh WS (2007) Oceanic methane biogeochemistry. Chem Rev 107:486-513

Robertson L, Kuenen J (2006) The colorless sulfur bacteria. In: Dworkin M, Falkow S, Rosenberg E, Schleifer K-H, Stackebrandt E (eds) The orokaryotes: ecophysiology and biochemistry. Springer, New York, NY, p 985-1011

> Robinson JL, Cavanaugh CM (1995) Rubisco in chemoautotrophic symbioses: implications for the interpretation of stable carbon isotope values. Limnol Oceanogr 40: 1496-1502

Robinson C, Bernhard J, Levin L, Mendoza G, Blanks J (2004) Surficial hydrocarbon seep infauna from the Blake Ridge(Atlantic Ocean, $2150 \mathrm{~m}$ ) and the Gulf of Mexico (690-2240 m). PSZNI: Mar Ecol 25:313-336

Sahling H, Rickert D, Lee RW, Linke P, Suess E (2002) Macrofaunal community structure and sulfide flux at gas hydrate deposits from the Cascadia convergent margin, NE Pacific. Mar Ecol Prog Ser 231:121-138

Schratzberger M, Whomersley P, Warr K, Bolam SG, Rees HL (2004) Colonisation of various types of sediment by estuarine nematodes via lateral infaunal migration: a laboratory study. Mar Biol 145:69-78

Seeberg-Elverfeldt J, Schlüter M, Feseker T, Kölling M (2005) Rhizon sampling of pore waters near the sediment/ water interface of aquatic systems. Limnol Oceanogr Methods 3:361-371

Shirayama Y, Ohta S (1990) Meiofauna in a cold-seep community off Hatsushima, Central Japan. J Oceanogr 46: 118-124

Soetaert K, Franco M, Lampadariou N, Muthumbi A, Steyaert M, Vandepitte L, vanden Berghe E, Vanaverbeke J (2009) Factors affecting nematode biomass, length and width from the shelf to the deep sea. Mar Ecol Prog Ser 392:123-132

> Somoza L, Diaz-del-Rio V, Leon R, Ivanov M and others (2003) Seabed morphology and hydrocarbon seepage in the Gulf of Cadiz mud volcano area: acoustic imagery, multibeam and ultra-high resolution seismic data. Mar Geol 195:153-176

Spies R, DesMarais D (1983) Natural isotope study of trophic enrichment of marine benthic communities by petroleum seepage. Mar Biol 73:67-71

> Stewart FJ, Newton ILG, Cavanaugh CM (2005) Chemosynthetic endosymbioses: adaptations to oxic-anoxic interfaces. Trends Microbiol 13:439-448

Thiermann F, Vismann B, Giere O (2000) Sulphide tolerance of the marine nematode Oncholaimus campylocer- 
coides-A result of internal sulphur formation? Mar Ecol Prog Ser 193:251-259

- Van Gaever S, Moodley L, de Beer D, Vanreusel A (2006) Meiobenthos at the Arctic Hakon Mosby Mud Volcano, with a parental-caring nematode thriving in sulphiderich sediments. Mar Ecol Prog Ser 321:143-155

> Van Gaever S, Galéron J, Sibuet M, Vanreusel A (2009a) Deep-sea habitat heterogeneity influence on meiofaunal communities in the Gulf of Guinea. Deep-Sea Res II 56: 2259-2269

Van Gaever S, Moodley L, Pasotti F, Houtekamer M, Middelburg JJ, Danovaro R, Vanreusel A (2009b) Trophic specialisation of metazoan meiofauna at the Hakon Mosby Mud Volcano: fatty acid biomarker isotope evidence. Mar Biol 156:1289-1296

Van Gaever S, Olu-Le Roy K, Derycke S, Vanreusel A (2009c) Metazoan meiofaunal communities at cold seeps along the Norwegian margin: influence of habitat heterogeneity and evidence for connection with shallow-

Editorial responsibility: Paul Snelgrove, St. John's, Newfoundland, Canada water habitats. Deep-Sea Res I 56:772-785

> Van Rensbergen P, Depreiter D, Pannemans B, Moerkerke $G$ and others (2005) The El Arraiche mud volcano field at the Moroccan Atlantic slope, Gulf of Cadiz. Mar Geol 219:1-17

Vanreusel A, Andersen AC, Boetius A, Connelly D and others (2009) Biodiversity of cold seep ecosystems along the European margins. Oceanography (Wash DC) 22: $110-127$

Vanreusel A, De Groote A, Gollner S, Bright M (2010) Ecology and biogeography of free-living nematodes associated with chemosynthetic environments in the deep sea: a review. PLoS ONE 5:e12449

Vitiello P (1970) Nématodes libres marins des vases profondes du Golfe du Lion. II. Chromadorida. Tethys 2: 449-500

Wieser W (1953) Die Beziehung zwischen Mundhöhlengestalt, Ernährungsweise und Vorkommen bei freilebenden marinen Nematoden. Ark Zool 2:439-484

Submitted: June 17, 2010; Accepted: June 30, 2011

Proofs received from author(s): September 20, 2011 